\title{
SOSIALISASI DAN PELATIHAN PEMBUATAN APLIKASI INTERAKTIF DI BIDANG TEKNIK MESIN
}

\author{
Muhammad Hasbi ${ }^{1}$, Murdjani' ${ }^{2}$,Muhammad Kasim ${ }^{3}$, Wahidin ${ }^{4}$ \\ Teknik Mesin, Politeknik Negeri Banjarmasin, Indonesia \\ $\underline{\text { m.hasbi@poliban.ac.id }}^{\text {I }}$
}

\begin{abstract}
Knowledge and basic skills in operating computers today have become an unavoidable need. Various activities or activities of human life in modern times cannot be separated with the help of computers to make it easier, faster and more effective. For example human work activities related to computers include: work with word processing (word processing), work with tables (table processing), reading news, browsing articles on the internet, playing games, sending and receiving emails. So many human work tasks that can be done with the help of computers make many programs and applications designed for various purposes.

Engineering programs are special programs designed with the aim of helping humans to complete various calculations in the field of engineering. At this community service we want to provide knowledge and improve skills to high school / vocational students in Banjarmasin about designing applications or programs related to engineering, especially in the field of mechanical engineering, by providing training in the design of interactive applications in the field of mechanical engineering. The training method used in this training will be a combination of theory and practice, starting from the basic introduction to programming, identifier recognition, variable recognition and introduction of IDE (Integrated Development Environment) so that it is expected to make it easier for participants to master the material provided. Participants will also be given various examples of calculation case studies in the world of engineering which are then attempted to make the program application. The target of this community service activity is technical programming training services and publications that will be published are national service journals.
\end{abstract}

Keywords: Technical Programming Training, Community Service

\begin{abstract}
ABSTRAK
Pengetahuan dan keterampilan dasar dalam mengoperasikan komputer saat ini sudahlah menjadi kebutuhan yang tidak dapat dihindari lagi. Berbagai kegiatan atau aktivitas hidup manusia di jaman moderen ini tidak dapat lepas dengan bantuan komputer untuk membuatnya menjadi lebih mudah, cepat dan efektif. Sebagai contohnya aktivitas pekerjaan manusia yang berkaitan dengan komputer diantaranya: pekerjaan dengan pengolah kata (word processing), pekerjaan dengan tabel (table processing), membaca berita, browsing artikel di internet, bermain game, mengirim dan menerima email. Begitu banyaknya tugas pekerjaan manusia yang dapat dikerjakan dengan bantuan komputer membuat banyak program maupun aplikasi yang dirancang untuk berbagai tujuan.

Program teknik (engineering software) merupakan program khusus yang dirancang dengan tujuan untuk membantu manusia untuk menyelesaikan berbagai perhitungan dibidang teknik. Pada pengabdian masyarakat ini kami ingin memberikan pengetahuan dan meningkatkan keterampilan kepada siswa SMA/SMK di Banjarmasin tentang perancangan aplikasi atau program yang berkaitan dengan teknik khususnya dibidang
\end{abstract}


teknik mesin, dengan cara memberikan pelatihan perancangan aplikasi interaktif dibidang teknik mesin ini. Adapun metode pelatihan yang digunakan pada pelatihan ini nantinya adalah kombinasi dari teori dan praktek, dimulai dari pengenalan dasar pemrograman, pengenalan identifier, pengenalan variabel dan pengenalan IDE (Integrated Development Environment) sehingga diharapkan akan memudahkan peserta untuk menguasai materi yang diberikan. Peserta juga akan diberikan berbagai contoh studi kasus perhitungan dalam dunia teknik yang kemudian dicoba untuk dibuat aplikasi programnya. Target luaran dari kegiatan pengabdian masyarakat ini adalah jasa pelatihan pemrograman teknik dan publikasi yang akan diterbitkan adalah jurnal pengabdian nasional.

Kata Kunci: Pelatihan Pemrograman Teknik, Pengabdian Masyarakat

\section{PENDAHULUAN}

Banyaknya remaja pengguna komputer di SLTA maupun SMK yang tidak memiliki pengetahuan dan keterampilan dalam pemrograman komputer dibidang teknik, sedangkan pengetahuan dibidang ini akan sangat bermanfaat jika mereka nantinya akan melanjutkan jenjang studi yang lebih tinggi, misalnya melanjutkan program Diploma III atau program Strata 1 dibidang teknik. Masalah lainnya adalah umumnya para siswa SLTA maupun SMK tersebut telah memiliki sarana belajar seperti komputer atau laptop, namun lebih banyak menggunakannya hanya untuk bermain game yang jelas tidak produktif dan hanya akan mengganggu proses belajar. Kedua permasalahan tersebut yang sering terjadi pada mitra saat ini. Berdasar dari pertimbangan tersebut maka pengabdian masyarakat ini akan menyelenggarakan pelatihan pemrograman komputer dengan menggunakan compiler Delphi dengan harapan akan meningkatkan ketrampilan siswa dibidang ini.

Adapun tujuan dan manfaat dari kegiatan pelatihan pemrograman teknik pada program pengabdian masyarakat ini bagi siswa SMK Syuhada adalah untuk memberikan wawasan dan pengetahuan dasar tentang pemrograman teknik secara umum dan khususnya teknik mesin. Selain itu juga untuk memberikan keterampilan kepada siswa dalam hal merancang program yang berkaitan dengan aplikasi perhitungan teknik mesin

\section{METODE KEGIATAN}

Secara garis besar dalam merancang sebuah aplikasi atau program dengan menggunakan compiler Delphi diperlukan pengetahuan dasar dalam bidang pemrograman teknik diantaranya: pengetahuan tentang algoritma program, flowchart pemrograman, flowchart perhitungan teknik yang akan dijadikan program aplikasi, pengetahuan tentang variabel, identifier dan tentunya pengetahuan tentang compiler yang digunakan dalam pemrograman. Adapun diagram alir perancangan program dapat dijelaskan pada diagram dibawah ini. 


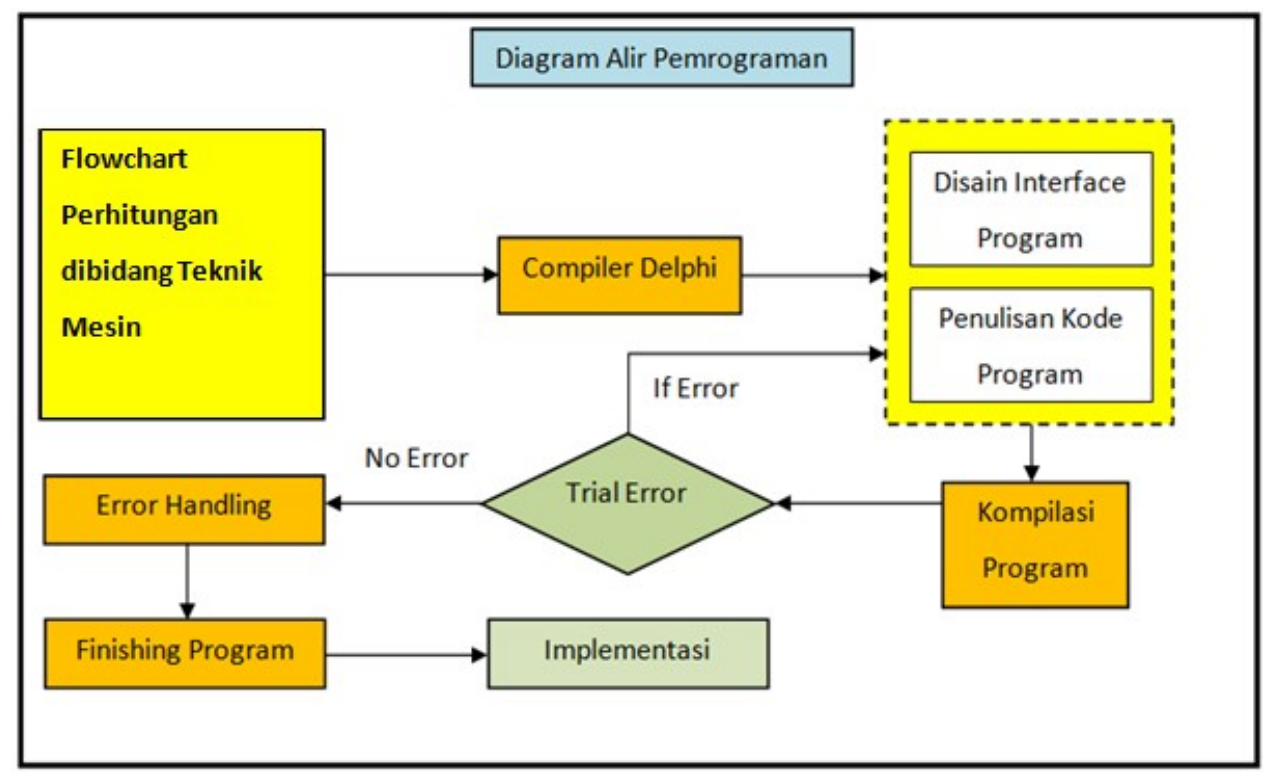

Gambar 1: Diagram Alir Pemrograman Aplikasi Teknik

(Sudiar, 2016) Pada gambar diagram alir pemrograman diatas dapat dijelaskan sebagai berikut: pada suatu kasus permasalahan maupun perhitungan dibidang teknik mesin, diambil flowchart perhitungan yang didalamnya dapat kita tentukan parameter dan variabel perhitungannya. Setelah semua datanya dikumpulkan sebagai persiapan awal dalam membuat program. Pada tahap berikutnya langkah pemrograman dikerjakan pada lingkungan kerja compiler Delphi, pada langkah ini dimulai proses pemrograman sampai dilangkah akhir implementasi program.

Metode pelaksanaan yang digunakan pada kegiatan pelatihan perancangan aplikasi interaktif ini adalah metode pertemuan atau tatap muka dengan peserta pelatihan dimana pada setiap pertemuan instruktur akan menjelaskan materi dimulai dari teori dasar sampai pada teori tingkat lanjut yang dikombinasikan dengan praktek membuat program atau aplikasi sederhana dibidang teknik mesin.

Tabel 1: Kegiatan dan Metode Pelatihan

\begin{tabular}{|c|l|l|l|}
\hline No. & Kegiatan Pelatihan & Metode & Kegiatan Peserta \\
\hline 1. & Pengenalan teori dasar software & Penyampaian teori & Menyimak materi \\
\hline 2. & $\begin{array}{l}\text { Pengenalan konsep dasar } \\
\text { pemrograman }\end{array}$ & $\begin{array}{l}\text { Penyampaian teori } \\
\text { dan menunjukkan } \\
\text { contoh. }\end{array}$ & Menyimak materi \\
\hline 3. & $\begin{array}{l}\text { Pengenalan identifier dan reserve } \\
\text { word }\end{array}$ & $\begin{array}{l}\text { Penyampaian teori } \\
\text { dan menunjukkan } \\
\text { contoh. }\end{array}$ & $\begin{array}{l}\text { Menyimak materi } \\
\text { dan praktek } \\
\text { membuat variabel } \\
\text { program }\end{array}$ \\
\hline 4. & Pengenalan lingkungan IDE Delphi & $\begin{array}{l}\text { Penyampaian teori } \\
\text { dan menunjukkan } \\
\text { IDE pada toolbar. }\end{array}$ & $\begin{array}{l}\text { Praktek menginstal } \\
\text { compiler Delphi }\end{array}$ \\
\hline
\end{tabular}




\begin{tabular}{|c|l|l|l|}
\hline 5. & Pengenalan perintah dasar compiler & Teori dan Praktek & $\begin{array}{l}\text { Melakukan praktek } \\
\text { pada PC masing- } \\
\text { masing }\end{array}$ \\
\hline 6. & $\begin{array}{l}\text { Praktek merancang interface } \\
\text { program }\end{array}$ & Teori dan Praktek & $\begin{array}{l}\text { Melakukan praktek } \\
\text { pada PC masing- } \\
\text { masing }\end{array}$ \\
\hline 7. & $\begin{array}{l}\text { Praktek menulis kode program, } \\
\text { penanganan error dan langkah } \\
\text { kompilasi program. }\end{array}$ & $\begin{array}{l}\text { Melakukan praktek } \\
\text { pada PC masing- } \\
\text { masing }\end{array}$ \\
\hline
\end{tabular}

\section{HASIL DAN PEMBAHASAN}

Pada kegiatan pelatihan ini, para peserta tidak hanya diberikan materi dasar yang berkaitan dengan dasar pemrograman teknik namun diberikan pula praktek merancang program atau aplikasi teknik dari awal sampai program aplikasi dapat dijalankan dengan baik. Adapun terdapat 4 aplikasi yang dikerjakan saat melaksanakan praktek saat pelatihan pemrograman aplikasi teknik seperti yang dapat dilihat pada gambar dibawah ini.

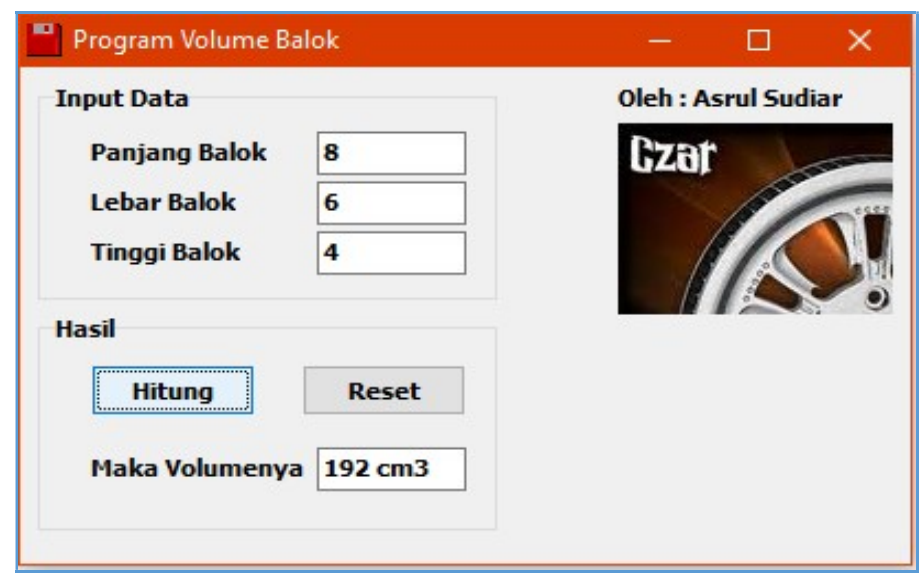

Gambar 2: Program Perhitungan Volume Balok

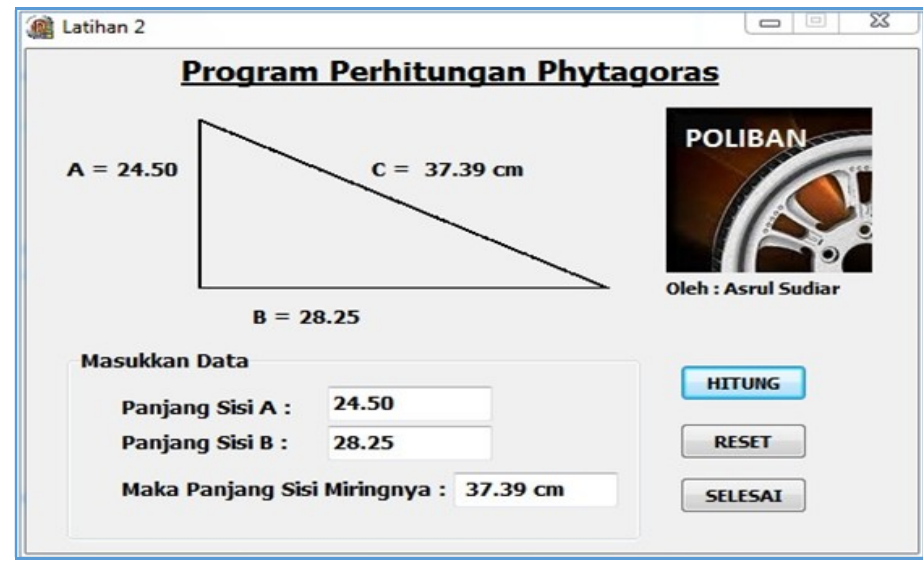

Gambar 3: Program Perhitungan Phytagoras 
Adapun hasil kegiatan selama praktek merancang aplikasi dibidang teknik mesin ini pada hari yang kedua dapat dilihat pada gambar berikut.

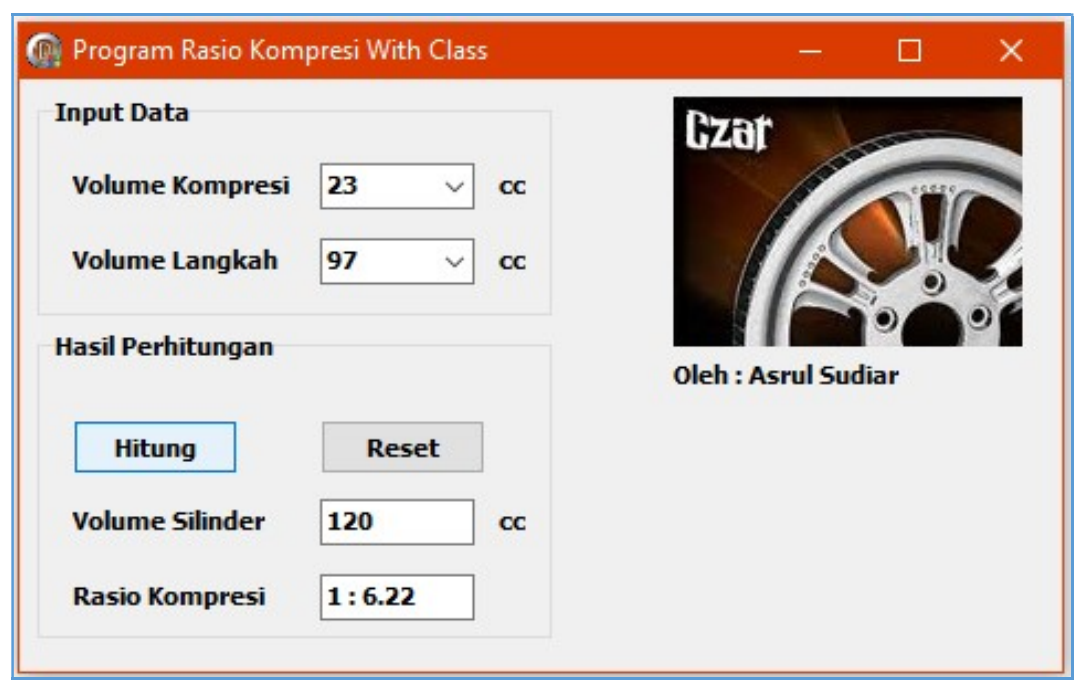

Gambar 4: Program Perhitungan Rasio Kompresi Mesin

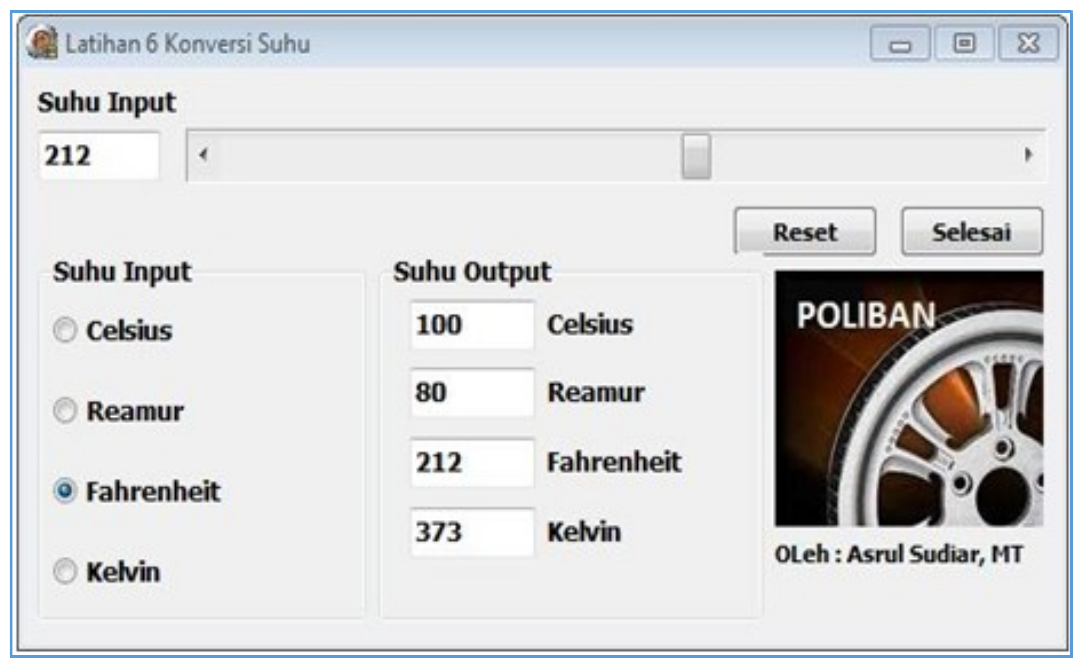

Gambar 5: Program Perhitungan Konversi Suhu Temperatur

\section{KESIMPULAN}

Kegiatan pengabdian ini mendapatkan respon positif dari pihak sekolah khususnya SMK Syuhada Banjarmasin yang menjadi mitra kami. Selama kegiatan para siswa yang menjadi peserta pelatihan dapat mengikuti semua materi yang diberikan oleh instruktur, mulai dari pengenalan teori dasar sampai dengan praktek merancang dan membuat aplikasi interaktif dibidang teknik mesin. Hal ini dapat dilihat dari kreatifitas para peserta dalam merancang dan mendisain program yang diberikan dalam modul pelatihan. Walaupun dalam pelaksanaannya pasti ditemui kendala berupa kesalahan penulisan sintaks kode program maupun kesalahan dalam pengoperasian compiler, namun hal tersebut merupakan hal yang 
umum terjadi bagi siapa saja yang baru saja mencoba merancang dan menulis kode program

\section{UCAPAN TERIMA KASIH}

Ucapan terima kasih juga merupakan bagian yang tidak wajib ada. Jika ada pihak luar yang terlibat di dalam pembuatan artikel ini, maka dapat dituliskan pada bagian ini. Ucapan terima kasih juga dapat ditujukan untuk pihak pemberi dana pengabdian.

\section{DAFTAR PUSTAKA}

Hartono, J. (2011). Pengenalan komputer. Andi Offset, Yogyakarta.

Panduan Pelaksanaan Penelitian dan Pengabdian Pada Masyarakat di Perguruan Tinggi Edisi XII Tahun 2018. Direktorat Riset dan Pengabdian Pada Masyarakat, Direktorat Jenderal Penguatan Riset dan Pengembangan, Kementerian Riset, Teknologi dan Pendidikan Tinggi.

Rencana Strategis Pengabdian Kepada Masyarakat Politeknik Negeri Banjarmasin Tahun 2017-2021.

Sudiar, A. (2016). Implementasi dan Perancangan Aplikasi Pada Perencanaan Bantalan dan Bearing. Jurnal Poros Teknik Poliban, 8(Desember 2016), $73-78$.

Suyitno. (2018). Pelatihan Komputer Bagi Perangkat Desa dan Karang Taruna di Purworejo. Laporan Pengabdian Masyarakat. 